Personalidade Acadêmica Homenageada:

Augustus B. Cochran III (Agnes Scott College)

\title{
AS MIGRAÇÕES AMBIENTAIS NA CONTEMPORANEIDADE E A NECESSIDADE DO RECONHECIMENTO DO REFÚGIO AMBIENTAL
}

\section{ENVIRONMENTAL MIGRATIONS IN CONTEMPORARY AND THE NEED FOR RECOGNITION OF ENVIRONMENTAL REFUGE}

\section{AICHA DE ANDRADE QUINTERO EROUD}

Graduanda do curso de Direito do Centro de Ensino Superior de Foz do Iguaçu CESUFOZ. Foz do Iguaçu - PR. E-mail: aichaeroud@hotmail.com

\section{ALCELYR VALLE DA COSTA NETO}

Advogado. Mestre (Mestrado Profissional) em Educação e novas Tecnologias pelo Centro Universitário Internacional - UNINTER. E-mail: avcostaneto@yahoo.com.br

\section{RESUMO}

É incontestável que o deslocamento de pessoas devido aos desastres ambientais e às mudanças climáticas decorrem desde os primórdios da civilização. Sua ocorrência pode se dar tanto de forma interna - dentro do país -, quanto externamente, onde se cruzam as fronteiras dos Estados em busca de um abrigo seguro em todos os aspectos. Não é por demais salientar, que essa situação de vulnerabilidade dos conhecidos "refugiados ambientais" (termo, atualmente, não utilizado pelo Direito Internacional considerando o Estatuto do Refugiado de 1951. Daí, por melhor dizer, migrantes ambientais) engloba uma preocupação de cunho global, haja vista que as problemáticas enfrentadas por essas pessoas vão além de encontrar um novo lar, considerando sua vulnerabilidade no sentido mais amplo, seja tanto na área social, econômica, emocional e cultural. No entanto, atualmente, existe 
Personalidade Acadêmica Homenageada:

Augustus B. Cochran III (Agnes Scott College)

a carência de um documento internacional que reconheça a própria migração ambiental como uma modalidade de migração forçada, apenas existindo documentos regionais para solucionar a questão. A importância desse reconhecimento é de grande valia, haja vista que os desastres ambientais e as mudanças climáticas estão aumentando a cada dia. Ainda, é pertinente ressaltar a relevância de se propor a alteração da nomenclatura de "migrante ambiental" para "refugiado ambiental" para conferir maiores direitos e garantias àqueles que tendem a se enquadrar na modalidade. Todavia, o "fundado temor de perseguição" é um dos elementos subjetivos constitutivos do refúgio, elemento este que não se incorpora na migração ambiental. No entanto, a violação aos Direito Humanos, nesse contexto, é nítida. Ademais, é ponderável ressaltar que, hodiernamente, por causa das ações humanas prejudiciais ao meio ambiente, os danos ambientais vêm ocorrendo com mais frequência e maior intensidade, irradiando severos efeitos nas comunidades atingidas, principalmente, pela mudança climática, ocasionando cada vez mais os deslocamentos forçados por motivos ambientais. Essas alterações devem ser observadas sob a perspectiva dos Direitos Humanos, como forma de assegurar tanto o direito ao meio ambiente equilibrado quanto o direito à dignidade dos migrantes ambientais. Com efeito, é perceptível que a problemática ambiental desconhece as fronteiras, sendo os seus impactos produzidos num determinado país, mas as sequelas são tendentes a irradiar efeitos no plano global. A metodologia empregada para o presente estudo é a pesquisa qualitativa e quantitativa, de recuperação bibliográfica com aportes documentais. Como fundamento dos argumentos expostos, utiliza-se a Declaração Universal dos Direitos Humanos e a Convenção Relativa ao Estatuto dos Refugiados de 1951. A metodologia aplicada no presente estudo tem por intuito almejar como resultado mediato e imediato, a demonstração da importância da criação de um mecanismo global específico para enfrentar a problemática em comento, considerando a migração ambiental como um problema mundial, e não somente regional, visando a proteção e reconhecimento dos direitos dos deslocados ambientais sob a ótica dos Direitos Humanos, afirmando a ampliação do conceito de 
Personalidade Acadêmica Homenageada:

Augustus B. Cochran III (Agnes Scott College)

refugiado para amoldar e preencher essa lacuna jurídica no âmbito do Direito Internacional.

PALAVRAS-CHAVE: Migração Ambiental; Mudança Climática; Refúgio; Desastres Naturais.

\section{REFERÊNCIAS}

SILVA, José Carlos Loureiro da. Deslocados pelo meio ambiente. Revista Jurídica UNICURITIBA, V. 1, ํo. 38, pp. 175-194. Curitiba: 2015. Disponível em: http://revista.unicuritiba.edu.br/index.php/RevJur/article/view/1271/832. Acesso em: 02 de jun. de 2019.

ASSEMBLEIA GERAL DA ONU. Declaração Universal dos Direitos Humanos. Nações Unidas, Paris: $1948 . \quad$ Disponível em: https://www.ohchr.org/EN/UDHR/Pages/Language.aspx?LangID=por. Acesso em: 02 de jun. de 2019.

FIORILLO, Celso Antonio Pacheco. Curso de direito ambiental brasileiro. 14. ed. rev., ampl. e atual. São Paulo: Saraiva, 2013.

TRINDADE, Antônio Augusto Cançado. Direitos humanos e meio-ambiente: paralelo dos sistemas de proteção internacional. 1. ed., Sergio Antonio Fabris Editor. Porto Alegre: 1993. 